\title{
Composition of semi-volatile organic compounds in the urban atmosphere of Singapore: influence of biomass burning
}

\author{
J. He ${ }^{1,2}$, B. Zielinska ${ }^{3}$, and R. Balasubramanian ${ }^{2,1}$ \\ ${ }^{1}$ Singapore - Delft Water Alliance, Block E1, \#08-25, 1 Engineering Drive 2, National University of Singapore, \\ Singapore 117576, Singapore \\ ${ }^{2}$ Division of Environmental Science and Engineering, Block EA, \#03-12, 9 Engineering Drive 1, National University of \\ Singapore, Singapore 117576, Singapore \\ ${ }^{3}$ Division of Atmospheric Sciences, Desert Research Institute, 2215 Raggio Parkway Reno, NV 89512-1095, USA
}

Received: 27 February 2010 - Published in Atmos. Chem. Phys. Discuss.: 1 April 2010

Revised: 11 October 2010 - Accepted: 15 October 2010 - Published: 1 December 2010

\begin{abstract}
An intensive field study was conducted in the urban atmosphere of Singapore to investigate the composition of organic compounds in both gaseous and particulate phases during the period of August to early November 2006. 17 atmospheric samples were collected. These samples were subjected to accelerated solvent extraction with a mixture of dichloromethane and acetone and separated into functional group fractions for analyses by GC/MS. Over 180 organic compounds belonging to three major fractions (n-alkanes, polycyclic aromatic hydrocarbons - PAHs, and polar organic compounds - POCs) were identified and quantified. The characteristics and abundance of the n-alkanes, PAHs, mono and dicarboxylic acids, methoxylated phenols and other POCs were determined. The composition of these organic compounds fluctuated temporally with most of them being relatively higher in October than those in other months of the sampling period. 3-D backward air mass trajectory analyses together with the carbon preference index (CPI), molecular diagnostic ratios and molecular markers were used to investigate the origin of organic species measured in this study. Based on these diagnostic tools, the increased abundance of atmospheric organic species during October could be attributed to the occurrence of regional smoke haze episodes due to biomass burning in Indonesia. Among the POCs investigated, phthalic acid and cis-pinonic acid were abundant during October 2006. These two acids showed strong linear relationships with maximum daily ozone con-
\end{abstract}

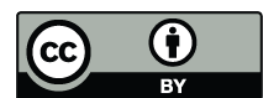

Correspondence to: R. Balasubramanian (eserbala@nus.edu.sg) centrations throughout the entire sampling period. This correlation with ozone suggested that the secondary aerosol constituents such as phthalic and cis-pinonic acids were probably formed through $\mathrm{O}_{3}$-induced photochemical transformation.

\section{Introduction}

Air pollution in Southeast Asia (SEA) is a subject of interest from both regulatory and scientific perspectives since regional emissions are growing rapidly as a result of increasing population, expanding economies, and the associated systems of energy consumption and production. The potential for trans-boundary air pollution problems in SEA is also great due to high emissions and the close proximity of many of the major industrial and urban centers (e.g. Bangkok, Kuala Lumpur, Singapore, and Jakarta). Regional air pollution problems such as reduced visibility and acid deposition are already apparent in the region (Balasubramanian et al., 1999, 2003; Siniarovina and Engardt, 2005; See et al., 2006). Partially because of the recurring regional haze episodes resulting from forest and peat fires (detailed background information in the Supplement), caused by land-clearing activities in Sumatra and Borneo, and to a lesser extent Malaysia, there has been an increase in the number of air quality monitoring stations in the region. These regional smoke haze episodes have occurred almost every dry season since the late 1990s in Southeast Asia (Fang et al., 1999; Narukawa et al., 1999; Muraleedharan et al., 2000; Mukherjee and Viswanathan, 2001; Koe et al., 2001; Bin Abas et al., 2004). Moderate and dense smoke from these fires could be transported from

Published by Copernicus Publications on behalf of the European Geosciences Union. 
South Sumatra and Kalimantan during the Southwest monsoon season such that the atmosphere over Singapore could be polluted by smoke haze to some extent. These smoke haze episodes are different from localized transient smog conditions occurring in urban areas from the trapping of anthropogenic emissions in a nearly stagnant atmosphere. The spread of smoke haze resulting from biomass burning could lead to some local and regional air pollution problems over this area.

Among air pollutants, airborne particulate matter (PM) is unique because of its potential complexity in terms of both chemical composition and physical properties. In order to understand the role of PM in regional air pollution and atmospheric chemistry issues, it is important to know their detailed chemical composition. A number of studies on PM compositions in SEA have been reported, but most of these studies were focused on measuring specific aerosol components (e.g. total mass, elements, organic carbon/elemental carbon (OC/EC) and water-soluble ionic and organic species over a limited period of time (Takeuchi et al., 1998; Gras et al., 1999; Nakajima et al., 1999; Narukawa et al., 1999; Radojevic and Hassan, 1999; Muraleedharan et al., 2000; Okada et al., 2001; Salam et al., 2003). We did a comprehensive characterization of atmospheric aerosols in Singapore on a daily basis for a year (Balasubramanian et al., 2003) which revealed that a significant fraction of the total mass can be attributed to organic constituents.

Organic matter in aerosols is composed of a large number of individual compounds and is widespread in the environment. The typical sources include natural and anthropogenic emissions such as forest fires, volcanic eruptions, incomplete combustion of fossil fuels, wood, agricultural debris or leaves, and fugitive emissions from industrial processes ( $\mathrm{Si}$ moneit et al., 1977; Simoneit, 1984; Rogge et al., 1993; Fang et al., 1999; Fraser et al., 1999; Schauer et al., 2007). PM can also be formed from nucleation of atmospheric transformation products of volatile organic compounds (VOCs) or their adsorption on the surface of the pre-existing aerosol (Pandis et al., 1992; Penner and Novakov, 1996). Formation of secondary organic aerosol (SOA) has been extensively studied under simulated laboratory conditions in the last two decades (Seinfeld and Pankow, 2003). However, data on detailed speciation of organic species in urban aerosols especially in SEA are still limited. This is probably due to analytical difficulties and the complexity of the compounds present.

To improve our knowledge on the particulate air pollution in SEA and to address the needs for a comprehensive characterization of PM and their effects, it is necessary to have information on the detailed chemical composition of urban organic aerosols. An important aspect with regard to the atmospheric fate of organic aerosols is that semi-volatile organic compounds (SVOCs) such as n-alkanes, polycyclic aromatic hydrocarbons (PAHs) and polychlroniated biphenyls (PCBs) tend to be partitioned between the gas and particle phases which could affect their transport and transformation in ur- ban atmospheres. We recently studied the gas/particle partitioning of PAHs and PCBs in the tropical atmosphere of SEA based on both absorption and adsorption models (He and Balasubramanian, 2009).

In the present study, the compositions of the nonpolar and polar organic compounds in both gas and particulate phases were determined from August through early November 2006 in order to determine temporal variability. Molecular distributions and concentrations of n-alkanes, PAHs and POCs were quantified under different meteorological conditions. Based on molecular distributions of the compounds studied, biomass burning and other potential emission sources for the atmospheric particles were assessed and suggested. This article represents the first study of its kind on reporting the detailed chemical composition of organic aerosols for Singapore.

\section{Experimental}

\subsection{Sample collection}

SVOCs distributed between particulate and gaseous phases were collected from August to early November 2006 by a high-volume sampler (Model: PUF-3300 BRL, HI-Q Environmental, USA) at the Atmospheric Research station with a $12 \mathrm{~h}$ or $24 \mathrm{~h}$ sampling time; this site is located on the roof of one of the tallest buildings at the National University of Singapore campus. Singapore is located at the southern tip of the Malayan Peninsula, between latitudes $1^{\circ} 09^{\prime} \mathrm{N}$ and $1^{\circ} 29^{\prime} \mathrm{N}$ and longitudes $103^{\circ} 36^{\prime} \mathrm{E}$ and $104^{\circ} 25^{\prime} \mathrm{E}$, and measures $42 \mathrm{~km}$ from aast to west and $23 \mathrm{~km}$ north to south. The sampling site is $67 \mathrm{~m}$ a.s.1., and is approximately $800-1000 \mathrm{~m}$ away from the open sea. The air quality at the sampling site is influenced by local emissions from chemical industries, major power plants, and petroleum refineries located in the southwest direction and also by urban vehicular traffic. There are two main seasons, the Northeast Monsoon from November through February and the Southwest Monsoon from July through October. These two seasons are separated by two relatively short inter-monsoon periods, with winds blowing in no fixed direction. The months of February and March are relatively drier.

Total suspended particles (TSP) were collected by a prefired quartz filter of $10.2 \mathrm{~cm}$ diameter followed by an adsorbent cartridge filled with 3 pieces of $2.54 \mathrm{~cm}$ PUF plugs connected in series $(7.62 \mathrm{~cm})$ which were used to trap organic compounds partitioned into gas phase. These filters were annealed at $450^{\circ} \mathrm{C}$ for $24 \mathrm{~h}$ prior to use. Pre-cleaning of PUF plugs was carried out using $33 \mathrm{~mL}$ stainless steel vessels of a Dionex ASE 200 with the pure hexane, mixture of hexane and acetone (3:1) and pure acetone for two cycles, respectively, to remove the possible interference from organic compounds of non-polarity, semi-polarity and high polarity. To check whether the PUF plugs were sufficiently clean after 
the pre-cleaning procedure, one more cycle (hexane, mixture, and acetone) of extraction was applied. Their extracts were analyzed by the same GC-MS protocols as used for the target compounds in this study. It was found that their concentrations were detected at the same level as in pure solvents used for pre-cleaning. The high-volume PUF sampler can collect air at a rate of ca. $250 \mathrm{~L} \mathrm{~min}^{-1}$. After sampling, PUF plugs were wrapped in pre-cleaned aluminum foil and stored in moisture-free and air-tight glass containers, while particulate filters were conditioned in a desiccator for $24 \mathrm{~h}$, weighed, wrapped and placed with paired PUF plugs. The samples were stored $-20^{\circ} \mathrm{C}$ before they were shipped to the collaborator's laboratory in the Department of Atmospheric Sciences at Desert Research Institute (Nevada, US) for GC-MS analysis. The sampling information is provided in Table 1.

\subsection{Analytical methodology}

A detailed description of the analytical procedure used for extraction, separation and analysis of the main organic fractions has been published elsewhere (Rinehart et al., 2006; Mazzoleni et al., 2007). Briefly, several isotopically labeled internal standards were added to each quartz filter and PUF cartridge sample prior to extraction. Those quartz filters paired with PUF samples were extracted by accelerated solvent extraction (Dionex ASE 300 Accelerated Solvent Extrator by using $34 \mathrm{~mL}$ extraction cells at the pressure of $7000 \mathrm{~Pa}$ and the temperature of $70^{\circ} \mathrm{C}$ ) with dichloromethane followed by acetone; these extracts were then combined and concentrated by rotary evaporation followed by moisturefiltered ultra high purity (UHP) nitrogen blow down and then split into two fractions. The first fraction was analyzed without further alteration for PAHs and n-alkanes by gas chromatography coupled with mass spectrometry (GC/MS). The second fraction was evaporated to $100 \mu \mathrm{L}$ under moisture-filtered UHP nitrogen and transferred to $300 \mu \mathrm{L}$ silanized glass inserts. Samples were further evaporated to $50 \mu \mathrm{L}$ and $25 \mu \mathrm{L}$ of pyridine, and $150 \mu \mathrm{L}$ of BSTFA with $1 \%$ TMCS [N, O-bis (trimethylsilyl) trifluoroacetamide with $1 \%$ trimethylchlorosilane] was added. These derivatizing reagents convert the polar compounds into their trimethylsilyl derivatives for analysis of organic acids, methoxyphenols, cholesterol, sitosterol, etc. The glass insert containing the sample was put into a $2 \mathrm{ml}$ vial and sealed. The sample was then placed into a thermal plate (custom made) containing individual vial wells at $70{ }^{\circ} \mathrm{C}$ for $3 \mathrm{~h}$. The calibration solutions were freshly prepared and derivatized just prior to the analysis of each sample set, and then all samples were analyzed by $\mathrm{GC} / \mathrm{MS}$ within $18 \mathrm{~h}$ to avoid degradation. The samples were analyzed by electron impact ionization GC/MS technique using a Varian CP-3400 gas chromatograph with a model CP8400 Auto-sampler and interfaced to a Saturn 2000 Ion Trap Mass Spectrometer. Results are reported after blank subtraction with a composite field blank of 5 individual field blanks which were treated identically as above.

\subsection{Quality control}

The analytical quality of the data obtained was determined using the limit of detection (LOD), recovery, linearity of calibration, and by checking and eliminating sampling artifacts. During each set of extractions, the field blanks (filter and PUF plugs) were included and the mean blank value was subtracted from the measured levels. The reliability of the entire procedure for each sample was evaluated by using surrogate standards. Breakthrough was evaluated under field conditions by connecting three $2.5 \mathrm{~cm}$ plugs in series and analyzing them separately. For $24 \mathrm{~h}$ samples, measured semivolatile organic compounds (SVOCs) at the third plug were in the range of those found in blanks. Calibration standards spiked with internal standards were measured regularly to ensure the consistency of analytical instrument performance during chemical analysis.

\subsection{Airmass backward trajectory analysis}

The latest, updated Hybrid Single-Particle Lagrangian Integrated Trajectory (HYSPLIT) model (Version 4.9) (Draxler and Rolph, 2003; Rolph, 2003), developed by the National Oceanic and Atmospheric Administration (NOAA), was used to compute backward trajectories for air samples taken from August 2006 to November 2006. Meteorological data were obtained from National Centers for Environmental Prediction (NCEP) Global Data Assimilation System (GDAS, global, 2005-present). Kinematic 3-D trajectories were used as they are reported to provide an accurate description of the history of air masses in comparison with all of the other approaches (isentropic, isobaric) (Stohl, 1998; Stohl and Seibert, 1998). Backward air trajectories were generated at eight starting times per sample (every $3 \mathrm{~h}$ during each sampling event) for $96 \mathrm{~h}$ back in time with $500 \mathrm{~m}$ a.g.l. (above ground level). This atmospheric level is very frequently used (Lee et al., 2006; Erel et al., 2007) and ensures that the trajectory starts in the atmospheric boundary layer (ABL) (Dvorská et al., 2009). In addition, cluster analysis was conducted by using HYSPLIT model (version 4.9) as well to classify the trajectory groups of similar length and curvature for monsoon and pre-monsoon seasons (Stohl, 1998).

\section{Results and discussion}

\subsection{Trajectory analysis and temporal variations in TSP concentrations}

The $96 \mathrm{~h}$ backward trajectories of air masses arriving at the study site during this sampling period were computed, and are categorized in Fig. 1.

1. Cluster 1 - a category of air masses representative of Southwest monsoon season (August-September 2006). This category accounted for $98.6 \%$ of all the air masses 
Table 1. Summary of meteorological parameters, TSP and PSI data during the sampling period in 2006.

\begin{tabular}{lcccrr}
\hline Sampling Date & Air Temperature ${ }^{\circ} \mathrm{C}$ & Humidity $\%$ & Wind Speed $\mathrm{m} \mathrm{s}^{-1}$ & $\mathrm{TSP}_{\mu \mathrm{g} \mathrm{m}}{ }^{-3}$ & PSI \\
\hline 10-11 August & 26 & 84 & 1.7 & 46 & 42 \\
16-17 August & 27 & 83 & 3.1 & 43.7 & 45 \\
4-5 September & 29 & 78 & 1.9 & 39.3 & 47 \\
20-21 September & 29 & 74 & 3.3 & 39.4 & 44 \\
2-3 October & 28 & 76 & 1.1 & 80.5 & 68 \\
4-5 October & 28 & 77 & 2.5 & 57.9 & 53 \\
7-8 October & 28 & 79 & 1.6 & 217.9 & 130 \\
10 October-D & 30 & 70 & 1.8 & 127.5 & 59 \\
10-11 October-N & 26 & 81 & 0.4 & 108.8 & 71 \\
12 October-D & 29 & 73 & 1.5 & 63.1 & 54 \\
13-14 October-N & 25 & 78 & 1.2 & 57.7 & 85 \\
14-15 October & 28 & 78 & 1.4 & 134 & 116 \\
16-17 October & 28 & 80 & 0.8 & 123.4 & 118 \\
18-19 October & 29 & 76 & 0.8 & 128 & 87 \\
21-22 October & 29 & 79 & 0.7 & 64 & 69 \\
23-24 October & 28 & 88 & 0.3 & 43.9 & 38 \\
26-27 October & 28 & 89 & 0.6 & 32.6 & 37 \\
2-3 November & 27 & 86 & 0.8 & 49.8 & 58 \\
5-6 November & 28 & 84 & 0.6 & 37.0 & 35 \\
9-10 November & 28 & 05 & 0.8 & & \\
\hline
\end{tabular}

Note: $24 \mathrm{~h}$ sampling started from 08:00 a.m. to 08:00 a.m. next day.

D: daytime sampling started from 08:00 a.m. to 08:00 p.m. on the same day for $12 \mathrm{~h}$.

$\mathrm{N}$ : nighttime sampling started from 08:00 p.m. to 08:00 a.m. next day for $12 \mathrm{~h}$.

received at the sampling site during the SW monsoon. The air quality in Singapore was partially influenced by the air masses transported from Indonesia, and few hotspots (forest and peat fires) were observed in Sumatra and Kalimantan during this period as evident from satellite images (National Environment Agency (NEA), Singapore).

2. Cluster 2 - a category of air masses for October 2006. The pre-northeast monsoon, characterized by relatively low wind speeds, is usually experienced in the month of October. However, the air mass sources were still the same as those in August and September 2006, with $89.7 \%$ of air masses originating from the Southwest sector. These air masses were partly terrestrial and partly oceanic in origin, passing through islands of Southern Indonesia such as Sumba, Lombok and Sumbawa, Java Sea, mass islands of Java and Southwestern Sumatra, and in some cases crossing Kalimantan (Borneo) Island before arriving at Singapore. Notably, the number of dense hotspots detected in Sumatra and Borneo increased significantly during this month (representative hotspot map in Fig. 1d).

3. Cluster 3 - a category of air masses during early November 2006. $100 \%$ of air masses received at the site came from the Northeast (NE) areas (Fig. 1c). Most of air masses sampled were of oceanic character, trav- elling over the South China Sea; some originated from the Southern China such as Hainan, Canton provinces or Taiwan Island/strait as well. The air quality in Singapore was influenced by cleaner air masses of oceanic origin following their long-range transport from NE direction.

Figure 2 shows the daily average concentrations of TSP and Pollution Standard Index (PSI) readings which are indicative of ambient air quality. An index value of 1 to 50 indicates that the air quality is in the good range for that day, 51 to 100 in the moderate range and a value of $>100$ would mean that the air quality is unhealthy (NEA). As can be seen from Fig. 2, both the PSI and the TSP concentrations tracked each other reasonably well during this sampling period, suggesting that the PSI for the day was determined by the prevailing TSP concentrations. It could also be seen that there was a sporadic increase in the values of both the PSI (maximum 150) and the TSP (maximum $273.4 \mu \mathrm{g} \mathrm{m}^{-3}$ ) on a number of occasions during October which was presumably due to the influence of biomass burning-impacted air masses advected from Indonesia (Fig. 1b). As a result of the onset of the inter-monsoon season in early November, relatively cleaner oceanic air masses blew into Singapore (Fig. 1c), leading to a significant improvement in air quality as reflected by the PSI and TSP values. 

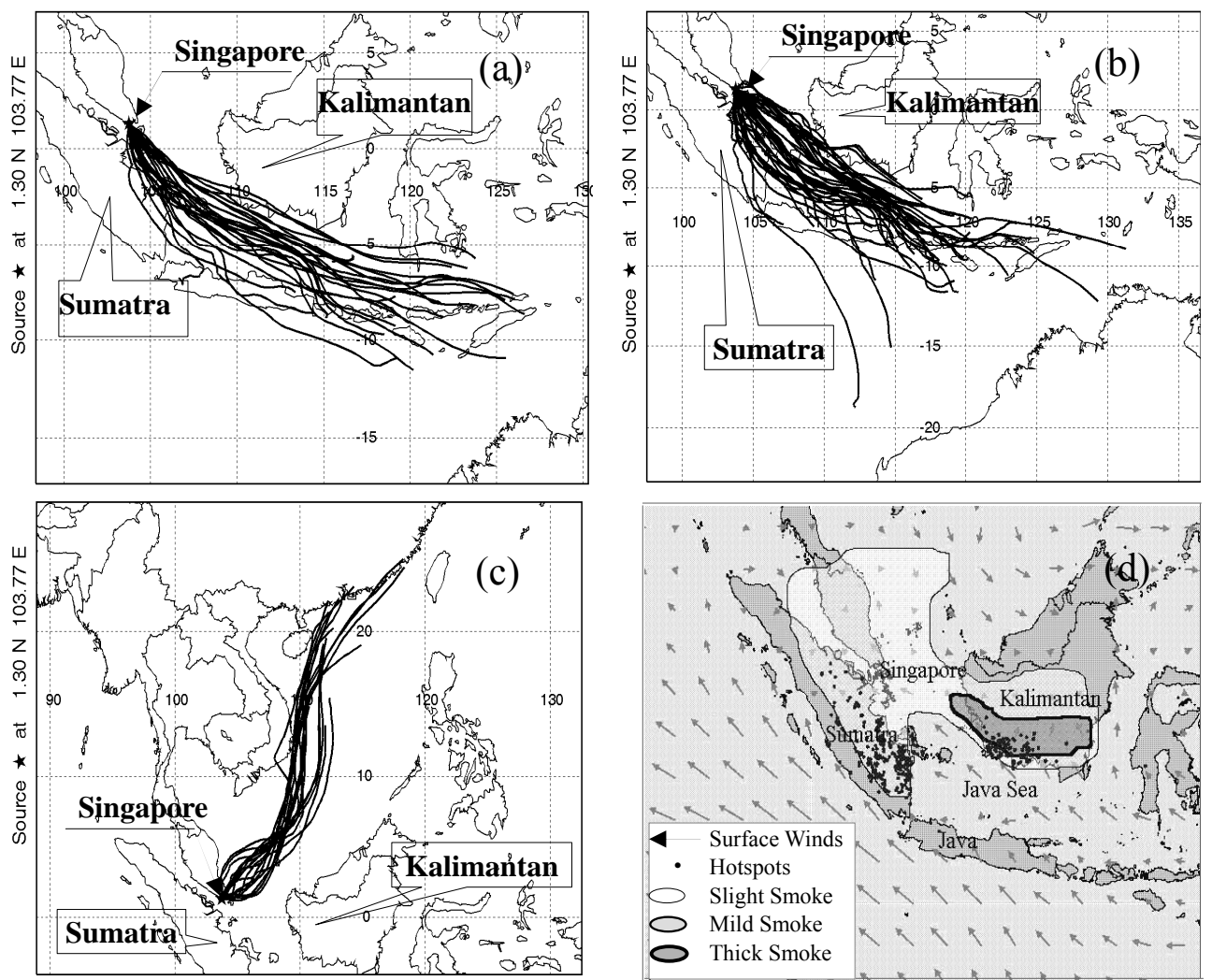

Fig. 1. Air mass backward trajectories from August to early November 2006 in Singapore and the representative distribution of hotspots in SEA in October 2006 (a) Cluster 1 (August-September 2006); (b) Cluster 2 (October 2006); (c) Cluster 3 (November 2006); (d) Hotspot map on 14 October 2006.

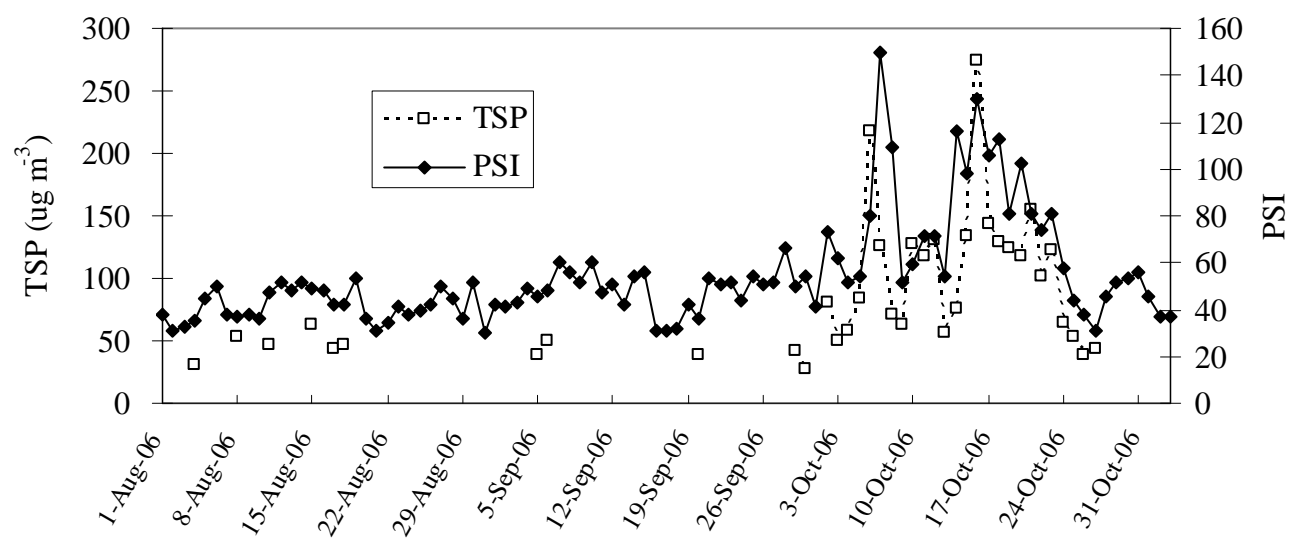

Fig. 2. Temporal Changes in Total Suspended Particulate matter (TSP) concentrations and Pollutants Standard Index (PSI) from August to October 2006 (PSI from National Environment Agency of Singapore).

\subsection{Aliphatic Hydrocarbons (AH)}

The measurement of the homologous series n-alkanes in the hydrocarbon fraction of the air samples allowed the determination of their occurrence, relative distribution, CPI, $\mathrm{C}_{\max }$ (carbon number maximum), and wax n-alkanes (WNA) content as shown in Table 2. The monthly average concen- trations (particulate plus gas) of $\mathrm{AH}$ were $66.13 \pm 11.04$, $45.32 \pm 2.91,801.34 \pm 443.96$ and $71.20 \pm 21.56 \mathrm{ng} \mathrm{m}^{-3}$ during August September, October and November 2006, respectively.

The number of carbons contained in $n$-alkanes detected in this study mainly ranged from $\mathrm{C}_{12}$ to $\mathrm{C}_{35}$ (some of the representative distributions are shown in Fig. 3). It has been 
Table 2. Organic compounds characteristics of air samples of 2006 over Singapore (total concentration of both gaseous and particulate phases, $\mathrm{ng} \mathrm{m}^{-3}$ ).

\begin{tabular}{|c|c|c|c|c|}
\hline Compound classes $\left(\mathrm{ng} \mathrm{m}^{-3}\right)$ & August 2006 & September 2006 & October 2006 & November 2006 \\
\hline \multicolumn{5}{|l|}{ n-alkanes } \\
\hline Total concentration & $66.13 \pm 11.04$ & $45.32 \pm 2.91$ & $801.34 \pm 443.96$ & $71.20 \pm 21.56$ \\
\hline \multicolumn{5}{|l|}{ Homologues range } \\
\hline $\mathrm{C}_{n} \max$ & $\mathrm{C}_{21}$ & $\mathrm{C}_{21}, \mathrm{C}_{22}$ & $\mathrm{C}_{21}, \mathrm{C}_{31}$ & $\mathrm{C}_{31}$ \\
\hline $\mathrm{CPI}_{1}$ & $1.20 \pm 0.21$ & $1.11 \pm 0.07$ & $1.59 \pm 0.10$ & $1.23 \pm 0.13$ \\
\hline $\mathrm{CPI}_{2}$ & $1.27 \pm 0.14$ & $1.06 \pm 0.23$ & $1.88 \pm 0.26$ & $1.56 \pm 0.32$ \\
\hline $\mathrm{CPI}_{3}$ & $1.48 \pm 0.44$ & $1.39 \pm 0.23$ & $1.77 \pm 0.18$ & $1.41 \pm 0.13$ \\
\hline WNA $(\%)$ & $10.88 \pm 4.89$ & $6.72 \pm 3.77$ & $35.75 \pm 3.58$ & $15.16 \pm 3.69$ \\
\hline \multicolumn{5}{|l|}{ PAHs } \\
\hline Non-alkylated & $10.08 \pm 3.89$ & $10.58 \pm 1.48$ & $16.33 \pm 10.63$ & $4.50 \pm 2.61$ \\
\hline Methyl-alkylated & $8.71 \pm 4.65$ & $4.60 \pm 1.06$ & $13.78 \pm 8.14$ & $4.93 \pm 0.74$ \\
\hline Oxygenated & $3.06 \pm 0.23$ & $1.90 \pm 0.66$ & $9.65 \pm 3.74$ & $4.14 \pm 1.42$ \\
\hline Others & $0.60 \pm 0.42$ & $0.15 \pm 0.16$ & $1.52 \pm 1.54$ & $0.21 \pm 0.26$ \\
\hline Flt $/($ Flt + Pyr $)$ & $0.44 \pm 0.05$ & $0.44 \pm 0.03$ & $0.52 \pm 0.02$ & $0.48 \pm 0.11$ \\
\hline Ind/(Ind + B(g, h, i)P $)$ & $0.35 \pm 0.02$ & $0.35 \pm 0.04$ & $0.54 \pm 0.11$ & $0.43 \pm 0.08$ \\
\hline $\mathrm{C}_{0} /\left(\mathrm{C}_{0}+\mathrm{C}_{1}\right) \mathrm{P} / \mathrm{A}$ & $0.44 \pm 0.02$ & $0.34 \pm 0.12$ & $0.52 \pm 0.10$ & $0.48 \pm 0.06$ \\
\hline $\mathrm{C}_{0} /\left(\mathrm{C}_{0}+\mathrm{C}_{1}\right) \mathrm{F} / \mathrm{P}$ & $0.56 \pm 0.05$ & $0.53 \pm 0.08$ & $0.80 \pm 0.05$ & $0.65 \pm 0.07$ \\
\hline \multicolumn{5}{|l|}{ Polar Compounds } \\
\hline n-Alkanoic acids & $96.97 \pm 1.05$ & $95.48 \pm 6.11$ & $301.56 \pm 132.44$ & $135.21 \pm 10.57$ \\
\hline CPI for n-alkanoic acids & $0.98 \pm 0.56$ & $1.30 \pm 0.42$ & $3.52 \pm 1.37$ & $1.57 \pm 0.97$ \\
\hline n-Alkanedioic acids & $83.12 \pm 6.92$ & $54.22 \pm 18.96$ & $217.22 \pm 40.76$ & $86.02 \pm 23.28$ \\
\hline Methyl-alkanedioic acids & $23.02 \pm 8.47$ & $9.73 \pm 3.76$ & $70.31 \pm 46.70$ & $5.97 \pm 2.41$ \\
\hline Anhydrosugar (levoglucosan) & 264.2. \pm 125.8 & $334.2 \pm 70.2$ & $2381.5 \pm 1239.8$ & $161.3 \pm 101.9$ \\
\hline Aromatic monocarboxylic acids & $190.96 \pm 58.70$ & $134.80 \pm 15.32$ & $316.43 \pm 125.72$ & $73.60 \pm 29.35$ \\
\hline Aromatic dicarboxylic acids & $6.82 \pm 3.65$ & $5.02 \pm 2.91$ & $18.38 \pm 3.98$ & $9.84 \pm 4.70$ \\
\hline Methoxylated phenols & $0.95 \pm 0.12$ & $1.31 \pm 0.31$ & $6.40 \pm 9.28$ & $2.27 \pm 0.90$ \\
\hline Others & $20.97 \pm 11.02$ & $13.49 \pm 2.26$ & $52.65 \pm 20.46$ & $24.19 \pm 15.45$ \\
\hline $\begin{array}{l}\text { Total concentration of } \\
\text { all organic compounds }\end{array}$ & $514.16 \pm 110.86$ & $379.56 \pm 56.59$ & $1831.47 \pm 658.1$ & $425.69 \pm 113.54$ \\
\hline
\end{tabular}

reported that a $C_{\max }$ in the range of 27 to 33 is characteristic of biogenic sources (higher plant wax) while a $\mathrm{C}_{\max }$ at lower carbon numbers may indicate a major input from petrogenic source (Gogou et al., 1996; Abas et al., 2004). In this study, the $\mathrm{C}_{\max }$ was at $\mathrm{C}_{21}$ or $\mathrm{C}_{22}$ for August and September samples, with monomodal distributions at low carbon numbers which is characteristic of dominant petrogenic sources, mostly from local urban emissions. However, during the first and third weeks of October, the $C_{\max }$ increased to $C_{31}$ (e.g. 7-8 October, 16-17 October 2006, Fig. 3) with peaks in both TSP and PSI values (Fig. 2), indicating a substantial contribution of higher plant wax from the smoke of biomass combustion for $n$-alkanes. The shift in the $C_{\max }$ to a higher carbon number could be attributed to the transport of biomass burning-impacted air masses from Indonesia (see Fig. 1) where more organic components could be emitted from the epicuticular waxes of vascular plants (Yassaa et al., 2001) or uncontrolled forest fires (Bin Abas et al., 2004). In addition, the $\mathrm{C}_{\max }$ diverged with bi-modal distributions of n-alkanes for those samples collected in the second week of October (e.g. 13-14 October 2006, Fig. 3). Early in November, the abundance of n-alkanes decreased to $71.20 \pm 21.56 \mathrm{ng} \mathrm{m}^{-3}$, but the $\mathrm{C}_{\max }$ was still centered at $\mathrm{C}_{31}$ (e.g. 2-4 November, 9-11 November 2006, Fig. 3), indicating that residual amounts of $n$-alkanes of pyrogenic (biomass burning) origin possibly still existed on a regional scale. The n-alkanes of pyrogenic origin include hentriacontane $\left(\mathrm{C}_{31} \mathrm{H}_{64}\right)$ and possibly heptacosane $\left(\mathrm{C}_{27} \mathrm{H}_{56}\right)$, noncosane $\left(\mathrm{C}_{29} \mathrm{H}_{60}\right)$, and triacontane $\left(\mathrm{C}_{30} \mathrm{H}_{62}\right)$ which showed a significant increase during the smoke haze period as compared to those during pre- and post-haze periods (see the supplementary table). The dominant $n$-alkanes emitted from local urban emissions include 

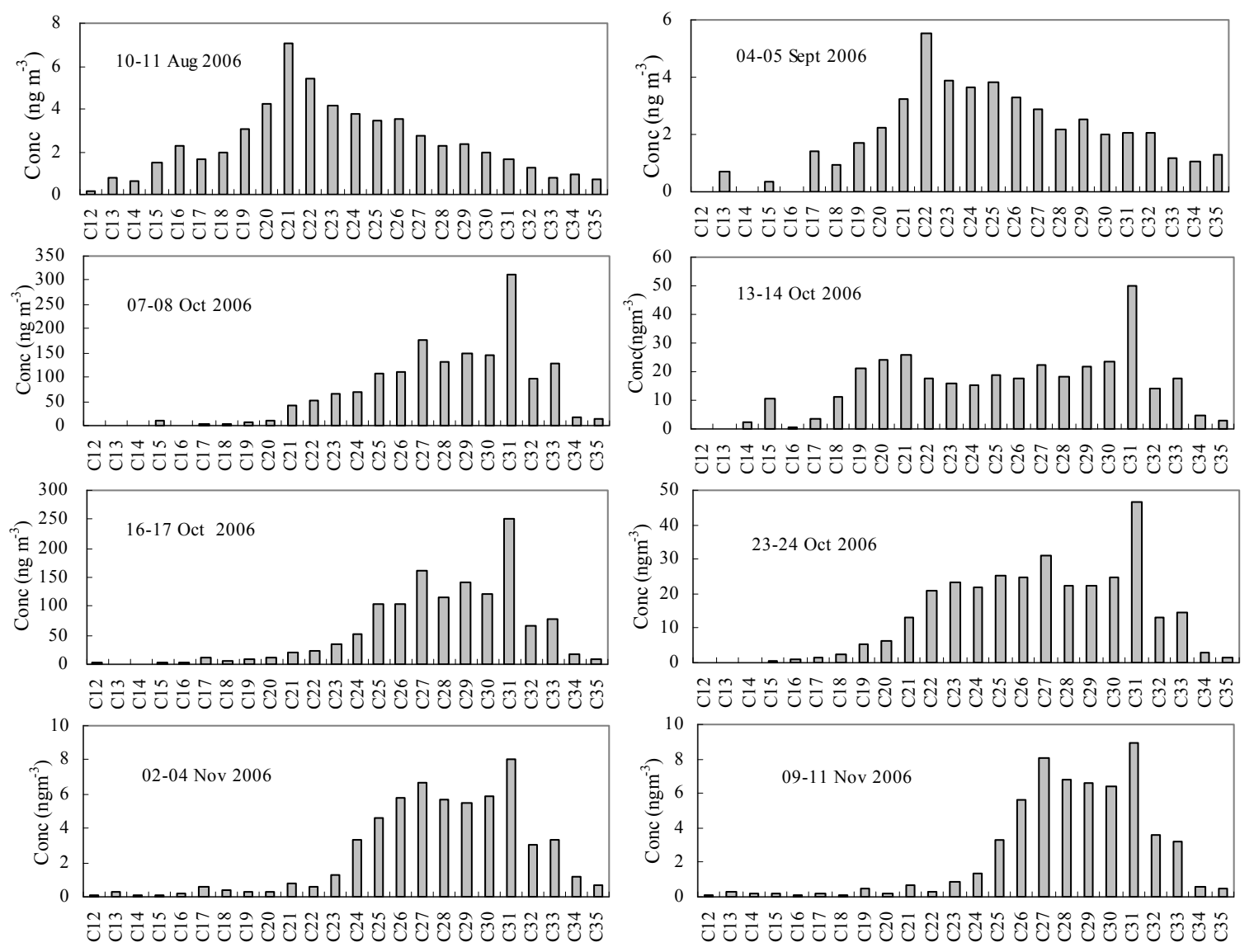

Fig. 3. Distributions of n-alkanes from August to November 2006.

heneicosane $\left(\mathrm{C}_{21} \mathrm{H}_{44}\right)$ and docosane $\left(\mathrm{C}_{22} \mathrm{H}_{46}\right)$ which did not large variations between pre- and post-haze periods. Figure 3 thus clearly indicates a significant change in the n-alkane profile from an anthropogenic source dominated pattern in the non-haze period to a biomass burning dominated pattern in the smoke haze period.

The CPI which expresses the ratio of odd-carbonnumbered to even-carbon-numbered n-alkanes in a given sample has been used to differentiate biogenic n-alkanes from those of petrogenic or anthropogenic origin (Simoneit and Mazurek, 1982; Simoneit, 1989; Zheng et al., 2000; Bi et al., 2002; Young, 2002). All the CPI values for n-alkanes were calculated as in Eqs. (1)-(3) (Kavouras et al., 1999):

i whole range for n-alkanes:

$$
\mathrm{CPI}_{1}=\sum\left(\mathrm{C}_{13}-\mathrm{C}_{35}\right) / \sum\left(\mathrm{C}_{12}-\mathrm{C}_{34}\right)
$$

ii petrogenic n-alkanes:

$$
\mathrm{CPI}_{2}=\sum\left(\mathrm{C}_{13}-\mathrm{C}_{25}\right) / \sum\left(\mathrm{C}_{12}-\mathrm{C}_{24}\right)
$$

iii biogenic n-alkanes:

$$
\mathrm{CPI}_{3}=\sum\left(\mathrm{C}_{25}-\mathrm{C}_{35}\right) / \sum\left(\mathrm{C}_{24}-\mathrm{C}_{34}\right)
$$

In general, CPI values $>2$ indicate predominant biogenic sources such as epicuticular waxes of terrestrial plants, and CPI values of near unity signify the source of fossil fuels or incomplete combustion of petroleum products (Simoneit, 1984; Wu et al., 2005). The average CPI values for the entire range $\left(\mathrm{CPI}_{1}\right)$, petrogenic $\left(\mathrm{CPI}_{2}\right)$ and biogenic/pyrogenic $\left(\mathrm{CPI}_{3}\right)$ for those samples collected during August, September and November 2006 were lower than those during October (Table 2). Although the influence of anthropogenic activities such as fossil fuel combustion, petroleum and diesel residues on the local air quality was evident from the CPI values $(<2)$, the contribution of biomass burning-related sources to the increased abundance of atmospheric organic compounds in October is particularly noteworthy.

Since n-alkanes derived from fossil or petroleum sources have CPI close to 1 , the residual plant WNA could be separated from fossil components by subtracting the corresponding n-alkane concentrations of CPI close to 1 (Simoneit, 1989; Simoneit et al., 1991). The plant WNA can be estimated through the following equations (Simoneit et al., 1991):

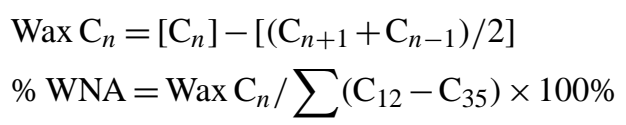


The highest plant WNA input with $35.75 \pm 3.58 \%$ was observed during October; the atmospheric samples collected during the months of August, September and November 2006 showed the plant wax n-alkanes inputs of $10.88 \pm 4.89 \%, 6.72 \pm 3.77 \%$ and $15.16 \pm 3.69 \%$, respectively. Both of CPI and \% WNA are based on the entire carbon range of $n$-alkanes $\left(\mathrm{C}_{12}-\mathrm{C}_{35}\right)$ in this study and can be considered as diagnostic indices for the source apportionment of plant wax alkanes. Their linear relationship was explored to determine the consistency of the source identification capabilities of these two indices. A strong linear relationship $\left(R^{2}=0.98\right)$ between WNA \% and $\mathrm{CPI}_{1}$ was observed as shown in Fig. 4. This correlation was slightly higher than those reported for other urban areas such as Guangzhou of China $\left(R^{2}=0.91\right)$ (Wu et al., 2005) and Greece $\left(R^{2}=0.95\right)$ (Gogou et al., 1996), indicating that the CPI and \% WNA could be used in the source assignments of atmospheric organic compounds including those in both the particulate and gaseous phases.

\subsection{Polycyclic aromatic hydrocarbons}

The levels of 93 PAH compounds including non-alkylated, methyl-alkylated, and oxygenated PAHs determined in this study are given in the Supplemental Table S1. The occurrence levels of PAHs during August, September and November 2006 were relatively lower than those in October. From 10 to 14 October, air samples were collected for $12 \mathrm{~h}$ (daytime and nighttime). The presence of non-alkylated and methyl-alkylated PAHs in the nighttime were 2-3 times higher than that in the daytime, which might be due to their degradation (photooxidation processes) in the daytime during the dry, oxidative environmental conditions of this period coupled with low wind speeds. This may also be due to different meteorological conditions during day and night, for example, lower inversion layer at night.

Since PAHs are produced and emitted through incomplete combustion processes, most of the PAHs cannot be used as exclusive markers for biomass combustion. Among the PAHs identified in this study, 1-methyl-7isopropylphenanthrene (retene) has been reported to be a molecular tracer compound for coniferous wood combustion which is formed by thermal degradation of resin compounds in the wood (Ramdahl, 1983; Standley and Simoneit, 1994; Oros and Simoneit, 2001). During most of the sampling period, retene was either non-detectable or existed with very low concentrations ( 2 to $7 \mathrm{pg} \mathrm{m}^{-3}$ ). However, its concentration was significantly higher in the month of October with its range between 6 and $73 \mathrm{pg} \mathrm{m}^{-3}$ and showed a moderate positive correlation with total PAHs with the $R^{2}$ of 0.52 (Fig. 5). Satellite images indicated that both peat and forest fires took place in Indonesia in October 2006 and conifer combustion occurred in Sumatra as dense hotspots were found there during the hazy period. This observation

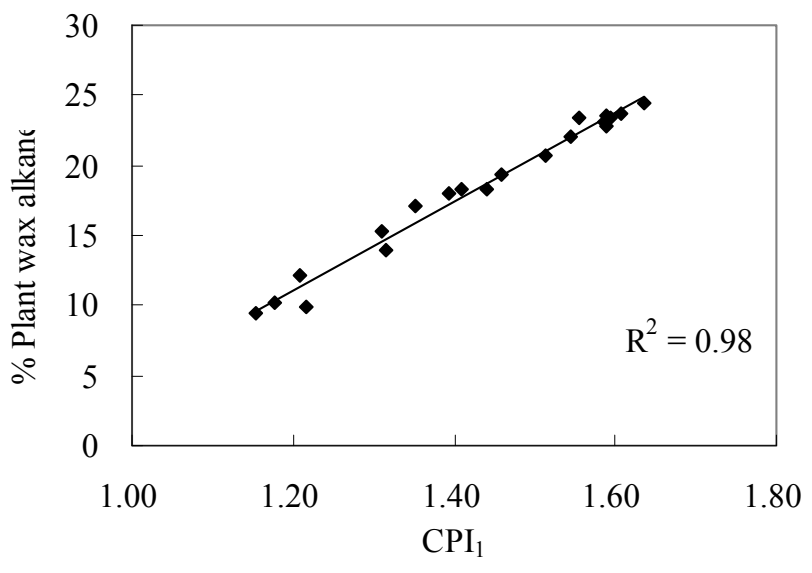

Fig. 4. Correlation of $\%$ plant wax alkane and $\mathrm{CPI}_{1}$.

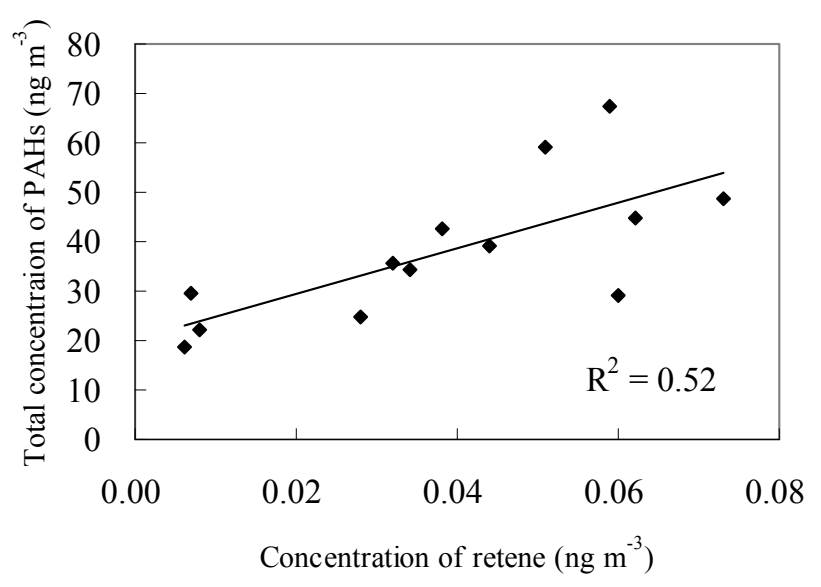

Fig. 5. Correlation between retene and total PAHs.

suggests that the atmospheric composition in Singapore was influenced by long-distance pyrogenic (biomass combustion) sources in Indonesia.

PAH concentration ratios have been widely used to identify combustion-derived PAHs (Benner et al., 1995; Yunker et al., 1996; Budzinski et al., 1997). In order to assess their potential sources in this study, a variety of PAH ratios were calculated for all air samples as listed in Table 2. It has been reported that fluoranthane/fluoranthane + pyrene (Flt/Flt + Pyr) ratios below 0.40 imply the contribution of unburned petroleum (petrogenic sources) and ratios between 0.40 to 0.50 suggest their emissions from the combustion of liquid fossil fuels (vehicle and crude oil), whereas ratios larger than 0.50 are characteristic of grass, wood, or coal combustion (Yunker et al., 2002). In addition, it has been suggested that indeno(1,2,3-cd)pyrene/indeno(1,2,3cd)pyrene + benzo $(g, h$, i)perylene (Ind/Ind + B (g, h, i)P) ratios lower than 0.20 likely imply petroleum emissions, ratios between 0.20 and 0.50 imply liquid fossil fuel combustion and those greater than 0.50 are indicative of grass, wood and coal combustion (Yunker, 2002). In this study, both of these two ratios Flt/(Flt + Pyr) and Ind/(Ind + B (g, h, i)P $)$ 
were between 0.30 and 0.48 for those samples collected during the months of August, September and November, suggesting the dominant contributions of local sources of PAHs such as emissions from on-road vehicles and petroleum industry in general. However, for samples collected in October 2006, these ratios were slightly greater than 0.50 , indicating biomass/peat combustion in Indonesia might contribute relatively more to the PAHs measured during this period. The relative abundance of $\mathrm{C}_{0}$ to $\mathrm{C}_{1}$ alkyl-PAH homologues $\left(\mathrm{C}_{1}-178\right.$ and 202 isomers) has also been used to distinguish between petroleum and combustion emissions, among which $\mathrm{C}_{0} / \mathrm{C}_{0}+\mathrm{C}_{1}$ MW178 (ratio of phenanthrene to phenanthrene plus anthracene plus $\mathrm{C}_{1}-178$ isomers) and $\mathrm{C}_{0} / \mathrm{C}_{0}+\mathrm{C}_{1}$ MW202 (ratio of fluoranthene to fluoranthene plus pyrene plus $\mathrm{C}_{1}-202$ isomers) were applied in this study (Gogou et al., 1996; Budzinski et al., 1997; Simo et al., 1997). In general, environmental samples with $\mathrm{C}_{0} / \mathrm{C}_{0}+\mathrm{C}_{1} \_\mathrm{MW} 202$ or $\mathrm{C}_{0} / \mathrm{C}_{0}+\mathrm{C}_{1} \_\mathrm{MW} 178$ below 0.5 supposedly indicate petroleum sources, while ratios higher than 0.50 are indicative of combustion emissions (Yunker, 2002). The average ratio of $\mathrm{C}_{0} / \mathrm{C}_{0}+\mathrm{C}_{1} \_\mathrm{MW} 202$, a better indicator of combustion sources other than petroleum (Yunker et al., 2002), was particularly higher $(>0.5)$ for the air samples collected in the month of October as compared to those for other months (Table 2), implying higher PAHs measured during this sampling duration could be due to regional combustion sources such as biomass and peat combustion.

It should be noted that PAH diagnostic ratios have some limitations for source assignments as stated by Galarneau (2008) due to various factors such as substantial intra-source variability and inter-source similarity of PAH isomer ratios, variations in PAH concentrations because of gas/particle partitioning, precipitation scavenging, particle deposition, etc. However, considering the fact that Singapore is a small but highly industrialized country with no distinct seasons in a year, there is little variation of atmospheric temperatures leading to relatively consistent gas/particle partitioning processes throughout the year. In this study, the effect of gas/particle partitioning variations on PAH diagnostic ratios was overcome by calculating diagnostic ratios of total PAH concentrations (gas plus particle). As reported by $\mathrm{He}$ and Balasubramanian (2008), organic compounds with more volatility tend to be redistributed onto larger particles while the less volatile compounds remain onto the fine particles with which they were directly emitted from their corresponding sources. From this distribution pattern, it is reasonable to assume that the compounds with similar volatility (LMW or HMW) may have similar particle scavenging efficiency by precipitation or similar dry deposition as the particle size distribution of PAH species is a major factor affecting the efficiency of the above-mentioned atmospheric removal processes. Based on these considerations, we hypothesize that the molecular diagnostic ratios of PAHs used in this study provide some insights into the temporal variations of their source profiles.

\subsection{Polar organic compounds}

A total of 63 polar organic compounds from both particulate and gaseous samples were detected as reported in a Supplemental Table S1, which include alkanoic acids, nalkanedioic acids, aromatic carboxylic acids, anhydrosugar (levoglucosan), and methoxylated phenols (Table 2).

$\mathrm{N}$-alkanoic acids ranged from $\mathrm{C}_{10}$ to $\mathrm{C}_{24}$ with a strong even carbon number predominance with total monthly concentrations ranging from 27.48 to $467.58 \mathrm{ng} \mathrm{m}^{-3}$ and with CPI between 0.46 and 4.63. During the sampling period with the exception of the month of October, myristic acid $\left(\mathrm{C}_{14}\right)$ was the most abundant species in most of the composites, followed by palmitic acid $\left(\mathrm{C}_{16}\right)$, which was presumably contributed by microbial activities and urban emissions ( $\mathrm{Si}$ moneit and Mazurek, 1982; Simoneit, 1984). However, in October 2006, $\mathrm{C}_{\max }$ was centered at $\mathrm{C}_{21}$ and $\mathrm{C}_{23}$, suggesting possible influence from biomass combustion sources of aerosols (Simoneit, 1984).

A series of alkanedioic acids (saturated dicarboxylic acids) were present in atmospheric samples, ranging from $\mathrm{C}_{4}$ to $\mathrm{C}_{14}$ (Supplemental Table S1). The alkanedioic acids could originate from a variety of sources in the environment. The $\mathrm{C}_{5}$ and $\mathrm{C}_{6}$ homologues are formed by the oxidation of cyclic olefins (Hatakeyama et al., 1985), while $\mathrm{C}_{8}$ and $\mathrm{C}_{9}$ ones are formed by the photo-oxidation of unsaturated carboxylic acids such as oleic $\left(\mathrm{C}_{18: 1}\right)$ and linoleic acids $\left(\mathrm{C}_{18: 2}\right)$ (Stephanou, 1993). As can be seen from Table S1, succinic acid $\left(\mathrm{C}_{4}\right)$ was predominant in most of the samples. This finding is consistent with earlier reports in the literature that succinic acid was the most abundant dicarboxylic acid in most of the urban atmosphere and was attributed to both vehicular emissions and biomass combustion (Kawamura, 1987; Rogge, 1998). The distribution of dicarboxylic acids was bimodal in the atmospheric samples collected during October, with the $\mathrm{C}_{\max }$ located at $\mathrm{C}_{4}$ and $\mathrm{C}_{10-12}$. High molecular weight alkanedioic acids $\left(n>\mathrm{C}_{10}\right)$ have been identified in rural aerosol particles and their source might be oxidation products of hydroxyl alkanoic acids from polyester biopolymer (Simoneit and Mazurek, 1982).

Anhydrosugars such as levoglucosan are known to be emitted from biomass burning (Abas et al., 2004; Iinuma et al., 2007; Simoneit, 2007; Simoneit et al., 1999). As shown in Fig. 7, levoglucosan concentrations were observed in the ranges of $170-380 \mathrm{ng} \mathrm{m}^{-3}, 350-7700 \mathrm{ng} \mathrm{m}^{-3}$, and $90-280 \mathrm{ng} \mathrm{m}^{-3}$, for August-September, October and early November in 2006, respectively. The correlations between levoglucosan and TSP were found to be high for both the entire sampling duration and the hazy period (October 2006) with $r^{2}$ up to 0.79 and 0.87 , respectively. The temporal trends of levoglucosan and TSP are quite similar during the entire sampling period, both of which showed significant peaks in October 2006, indicating that the air quality in Singapore was affected by the smoke haze transported from biomass burning sites in Indonesia during the hazy period. 
Substituted phenols, the lignin decomposition products as phenols with methoxy groups attached on the aromatic rings, were investigated in this study as well (Simoneit, 2002; Iinuma et al., 2007). Vanillin, 3-hydroxy-4-methoxybenzoic acid, was found to be most pronounced in this group of organic compounds with a peak occurrence $\left(19.16 \mathrm{ng} \mathrm{m}^{-3}\right)$ on 7-8 October 2006, which suggests vanillin emissions from biomass and peat combustion (Iinuma et al., 2007).

Among other polar organic compounds, both cis-3-acetyl2,2-dimethyl cyclobutaneacetic acid (cis-pinonic acid) and 1,2-benzenedicarboxylic acid (phthalic acid) merit special attention as they have been identified as photochemical products in smog chamber experiments and proposed as surrogates for the contribution of secondary organic aerosols (SOA) to ambient samples (Lee and Kamens, 2005; Ray and Mcdow, 2005; Park et al., 2006; Na et al., 2007). Cispinonic acid is one of the $\alpha$-pinene oxidation products (Jang and Kamens, 1999; Larsen et al., 2001) while phthalic acid is a product of naphthalene photodegradation (Bunce et al., 1997) and possibly photodegradation of other polycyclic aromatic hydrocarbons in atmospheric aerosols (Jang and McDow, 1997). The formation of these organic acids through atmospheric oxidation could be partially explored by comparing concentration trends between these compounds and ozone as shown in Fig. 6. Moderately strong linear relationships $\left(R^{2}=0.52-0.76\right)$ were obtained for all sampling periods, suggesting that more abundant phthalic acid and cispinonic acid, as secondary constituents, were formed during the hazy period, October 2006, through atmospheric oxidation processes such as $\mathrm{O}_{3}$ induced photo-degradations.

\section{Conclusions}

The molecular composition of organic compounds present in both gaseous and particulate atmospheric samples collected in Singapore from August to early November 2006 has been determined by GC-MS. In this study, a total of 17 samples were analyzed for over 180 organic compounds grouped into three major fractions (n-alkanes, PAHs and POCs). As for $n$-alkanes, the $\mathrm{C}_{\max }$ shifted from $\mathrm{C}_{20}-\mathrm{C}_{22}$ during August-September 2006 to $\mathrm{C}_{31}$ or bi-modal distributions at $\mathrm{C}_{21}$ and $\mathrm{C}_{31}$ in October 2006, indicating that organic pollutants in August-September 2006 samples were of dominant petrogenic signatures, while those from October 2006 were derived from vascular plant wax alkane inputs. In addition, the CPI values $\left(\mathrm{CPI}_{1}, \mathrm{CPI}_{2}, \mathrm{CPI}_{3}\right)$ increased from $1.15 \pm 0.14,1.17 \pm 0.19,1.44 \pm 0.29$ before October to $1.59 \pm 0.10,1.88 \pm 0.26,1.77 \pm 0.18$ during October 2006. On the average, $35.7 \%$ of n-alkanes came from plant wax emission or biomass combustion during October 2006; in contrast, only $9.6 \%$ of alkanes were of plant wax input from August to September 2006. The influence of biomass burning on the regional air quality is supported by the general increasing tendency of PAH diagnostic ratios dur-
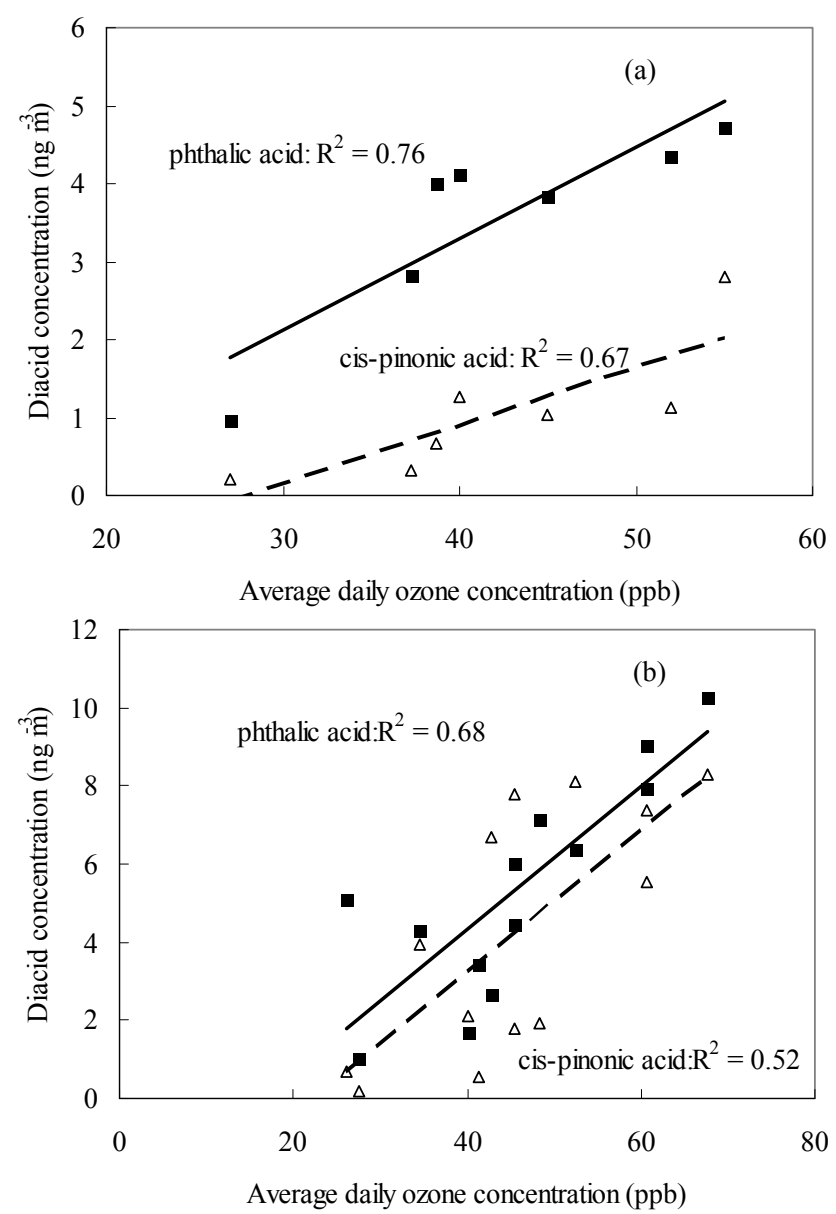

Fig. 6. Correlations between phthalic acid, cis-pinonic acid and ozone ( phthalic acid; $\Delta$ cis-pinonic acid; (a) August, September, November 2006; (b) October 2006).

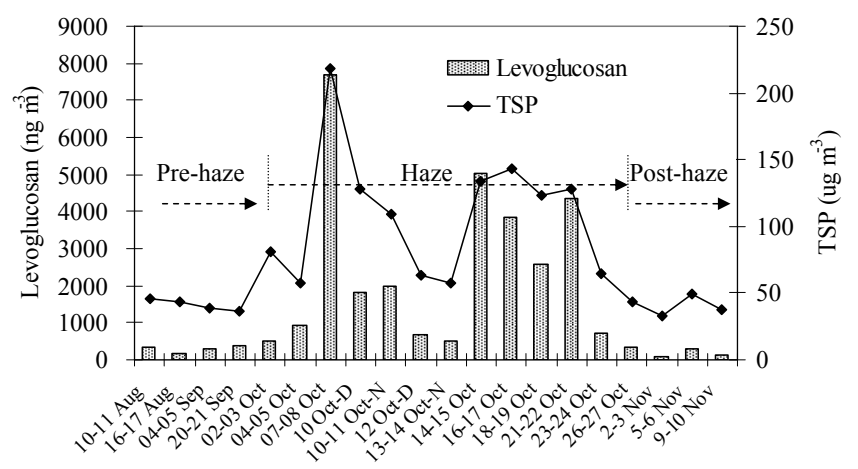

Fig. 7. Temporal trend of levoglucosan and TSP from August to October 2006.

ing October 2006 as compared to those investigated in other months. Among the polar organic compounds, which were converted to their trimethylsilyl derivatives and measured by GC/MS, organic acids and levoglucosan were the most abundant group detected in almost all samples, followed by 
methoxyphenols and sterols, etc. Our results suggest that the contribution of biomass burning inputs to the observed abundance of atmospheric organic compounds in Singapore during October 2006 was significant as compared to those found in other months of the sampling period.

\section{Supplementary material related to this article is available online at: http://www.atmos-chem-phys.net/10/11401/2010/ acp-10-11401-2010-supplement.pdf.}

Acknowledgements. One of the authors, Rajasekhar Balasubramanian, gratefully acknowledges the support from the Singapore-Delft Water Alliance (SDWA). The research presented in this work was carried out as part of the SDWA's research programme (R-264-001-013-272). Another author, Jun He, also thanks the World Future Foundation and Beijing Vantone Citylogic Investment Corp. for their joint support of this research.

Edited by: A Chen

\section{References}

Balasubramanian, R., Qian, W. B., Decesari, S., Facchini, M. C., and Fuzzi, S.: Comprehensive characterization of $\mathrm{PM}_{2.5}$ aerosols in Singapore, J. Geophys. Res.-Atmos., 108(D16), 4523, doi:10.1029/2002JD002517, 2003.

Balasubramanian, R., Victor, T., and Begum, R.: Impact of biomass burning on rainwater acidity and composition in Singapore, J. Geophys. Res., 104, 26881-26890, 1999.

Benner, B. A., Wise, S. A., Currie, L. A., Klouda, G. A., Klinedinst, D. B., Zweidinger, R. B., Stevens, R. K., and Lewis, C. W.: Distinguishing the contributions of residential wood combustion and mobile source emissions using relative concentrations of dimethyl-phenanthrene isomers, Environ. Sci. Technol., 29, 2382-2389, 1995.

Bi, X., Sheng, G., Peng, P., Chen, Y., Zhang, Z., and Fu, J.: Distribution of particulate- and vapor-phase n-alkanes and polycyclic aromatic hydrocarbons in urban atmosphere of Guangzhou,China, Atmos. Environ., 37, 289-298, 2002.

Bin Abas, M. R., Rahman, N. A., Omar, N. Y. M. J., Maah, M. J., Samah, A. A., Oros, D. R., Otto, A., and Simoneit, B. R. T.: Organic composition of aerosol particulate matter during a haze episode in Kuala Lumpur, Mallaysia, Atmos. Environ., 38, 4223-4241, 2004.

Budzinski, H., Jones, I., Bellocq, J., Pierand, C., and Carrigues, P.: Evaluation of sediment contamination by polycyclic aromatic hydrocarbons in the Gironde estuary, Mar. Chem., 58, 85-97, 1997.

Bunce, N. J., Liu, L., Zhu, J., and Lane, D. A.: Reaction of naphthalene and its derivatives with hydroxyl radicals in the gas phase, Environ. Sci. Technol., 31, 2252-2259, 1997.

Draxler, R. R. and Rolph, G. D.: HYSPLIT (Hybrid Single-Particle Lagrangian Integrated Trajectory) Model access via NOAA ARL READY, available at: http://www.arl.noaa.gov/ready/hysplit4. html, NOAA Air Resources Laboratory, Silver Springs, MD, USA, 2003.
Dvorská, A., Lammel, G., and Holoubek, I.: Recent trends of persistent organic pollutants in air in central Europe-Air monitoring in combination with air mass trajectory statistics as a tool to study the effectivity of regional chemical policy, Atmos. Environ., 43, 1280-1287, 2009.

Erel, Y., Kalderon-Asael, B., Dayan, U., and Sandler, A.: European atmospheric pollution imported by cooler air masses to the Eastern Mediterranean during the summer, Environ. Sci. Technol., 41, 5198-5203, 2007.

Fang, M., Zheng, M., Wang, F., To, K. L., Jaafar, A. B., and Tong, S. L.: The solvent-extractable organic compounds in the Indonesia biomass burning aerosols-characterization studies, Atmos. Environ., 33, 783-795, 1999.

Fraser, M. P., Simoneit, R. T., and Cass, G. R.: Particulate organic compounds emitted from motor vehicle exhaust and in the urban atmosphere, Atmos. Environ., 33, 2715-2724, 1999.

Galarneau, E.: Source specificity and atmospheric processing of airborne PAHs: Implications for source apportionment, Atmos. Environ., 42, 8139-8149, 2008.

Gogou, A., Stratigakis, N., Kanakidou, M., and Stephanou, E. G.: Organic aerosols in Eastern mediterranean: components source reconciliation by using molecular markers and atmospheric back trajectories, Org. Geochem., 25, 79-96, 1996.

Gras, J. L., Jensen, J. B., Okada, K., Ikegami, M., Zaizen, Y., and Makino, Y.: Some optical properties of smoke aerosol in Indonesia and Tropical Australia, Geophys. Res. Lett., 16, 1393-1396, 1999.

Hatakeyama, S., Tanokaka, T., Weng, J., Bandow, H., Takagi, H., and Akimoto, H.: Ozone-cyclohexene reaction in air: qualitative analysis of particulate products and the reaction mechanism, Environ. Sci. Technol., 19, 935-942, 1985.

He, J. and Balasubramanian, R.: Rain-aerosol coupling in the tropical atmosphere of Southeast Asia: distribution and scavenging ratios of major ionic species, J. Atmos. Chem. 60, 205-220, 2008.

He, J. and Balasubramanian, R.: A study of gas/particle partitioning of SVOCs in the tropical atmosphere of Southeast Asia, Atmos. Environ., 43, 4375-4383, 2009.

Hedberg, E., Johansson, C., Johansson, L., Swietlicki, E., and Brorström-Lundén, E.: Is levoglucosan a suitable quantitative tracer for wood burning?, Comparison with receptor modelling on trace elements in Lycksele, Sweden, J. Air Waste Manage. Assoc., 56, 1669-1678, 2006.

Iinuma, Y., Brüggemann, E., Gnauk, T., Müller, K., Andreae, M. O., Helas, G., Parmar, R., and Herrmann, H.: Source characterization of biomass burning particles: the combustion of selected European conifers, African hardwood, savanna grass, and German and Indonesian peat, J. Geophys. Res., 112, 1-26, 2007.

Jang, M. and Kamens, R. M.: Newly characterized products and composition of secondary aerosols from the reaction of alphapinene with ozone, Atmos. Environ., 33, 459-474, 1999

Jang , M. and McDow, S. R.: Products of benz[a]anthracene photodegradation in the presence of known organic constituents of atmospheric aerosols, Environ. Sci. Technol., 31, 1046-1053, 1997.

Kawamura, K. and Kaplan, I. R.: Motor exhaust emissions as a primary source for the dicarboxylic acids in Los Angeles ambient air, Environ. Sci. Technol., 21, 105-110, 1987.

Kavouras, I. G., Lawrence, J., Koutrakis, E. G., Stephanou, E. G., 
and Oyola, P.: Measurement of particulate aliphatic and polynuclear aromatic hydrocarbons in Santiago de Chile: source reconciliation and evaluation of sampling artifacts, Atmos. Environ., 33, 4977-4986, 1999.

Koe, L. C. C., Arellano, A. F., and McGregor, J. L.: Investigating the haze transport from 1997 biomass burning in Southeast Asia: Its impact upon Singapore, Atmos. Environ., 35, 27232734, 2001.

Larsen, B. R., Di Bella, D., Glasius, M., Winterhalter, R., Jensen, N. R., and Hjorth, J.: Gas-phase $\mathrm{OH}$ oxidation of monterpenes: gaseous and particulate products, J. Atmos. Chem., 38, 231-276, 2001.

Lee, K. H., Kim, Y. J., and Kim, J. J.: Characteristics of aerosol observed during two severe haze events over Korea in June and October 2004, Atmos. Environ., 40, 5146-5155, 2006.

Lee, S. and Kamens, R. M.: Particle nucleation from the reaction of alpha-pinene and $\mathrm{O}_{3}$, Atmos. Environ., 39, 6822-6832, 2005.

Leithead, A., Li, S. M., Hoff, R., Cheng, Y., and Brook, J.: Levoglucosan and dehydroabietic acid: Evidence of biomass burning impact on aerosols in the Lower Fraser Valley, Atmos. Environ., 40, 2721-2734, 2006.

Mazzoleni, L. R., Zielinska, B., and Moosmüller, H.: Emissions of Levoglucosan, Methoxy Phenols, and Organic Acids from Prescribed Burns, Wildland Fuels, and Residential Wood Combustion, Environ. Sci. Technol., 41(7), 2115-2122, 2007.

Medeiros, P. M., Conte, M. H., Weber, J. C., and Simoneit, B. R. T.: Sugars as source indicators of biogenic organic carbon in aerosols collected above the Howland Experimental Forest, Maine, Atmos. Environ., 40, 1694-1705, 2006.

Muhle, J., Lueker, T. J., Su, Y., Miller, B. R., Prather, K. A., and Weiss, R. F.: Trace gas and particulate emissions from the 2003 southern California wildfires, J. Geophys. Res. Atmos., 112(D3), 1-12, 2007.

Mukherjee, P. and Viswanathan, S.: Contributions to CO concentrations from biomass burning and traffic during haze episodes in Singapore, Atmos. Environ., 35, 715-725, 2001.

Muraleedharan, T. R., Radojevic, M., Waugh, A., and Caruna, A.: Chemical characterization of the haze in Brunei Darussalam during the 1998 episode, Atmos. Environ., 34, 2725-2731, 2000.

Na, K., Song, C., Switzer, C., and Cocker, D. R.: Effect of ammonia on secondary organic aerosol formation from alpha-pinene ozonolysis in dry and humid conditions, Environ. Sci. Technol., 41, 6096-6102, 2007.

Nakajima, T., Higurashi, A., Takeuchi, N., and Herman, J. R.: Satellite and ground-based study of optical properties of 1997 Indonesian forest fire aerosols, Geophys. Res. Lett., 26, 2421-2424, 1999.

Narukawa, M., Kawamura, K., Takeuchi, N., and Nakajima, T.: Distribution of dicarboxylic acids and carbon isotopic compositions in aerosols from 1997 Indonesian forest fires, Geophys. Res. Lett., 26, 3101-3104, 1999.

NEA: Singapore National Environmental Agency, available at: http: //app2.nea.gov.sg/psi.aspx, 2006.

Okada, K., Ikegami, M., Zaizen, Y., Makino, Y., Jensen, J. B., and Gras, J. L.: The mixture of individual aerosol particles in the 1997 Indonesian haze episode, J. Aerosol Sci., 32, 1269-1279, 2001.

Oros, D. R. and Simoneit, B. R. T.: Identification and emission factors of molecular tracers in organic aerosols from biomass burning Part 1, Temperate climate conifers, Appl. Geochem., 16, 1513-1544, 2001.

Pandis, S. N., Harley, R. A., Cass, G. R., and Seinfeld, J. H.: Secondary Organic Aerosol Formation and Transport, Atmos. Environ. Gen. Top., 26, 2269-2282, 1992.

Park, S. S., Bae, M. S., Schauer, J. J., Kim, Y. J., Cho, S. Y., and Kim, S. J.: Molecular composition of $\mathrm{PM}_{2.5}$ organic aerosol measured at an urban site of Korea during the ACE-Asia campaign, Atmos. Environ., 40, 4182-4198, 2006.

Penner, J. E. and Novakov, T.: Carbonaceous particles in the atmosphere: A historical perspective to the Fifth International Conference on Carbonaceous Particles in the Atmosphere, J. Geophys. Res.-Atmos., 101(D14), 19373-19378, 1996.

Radojevic, M. and Hassan, H.: Air quality in Brunei Darussalam during the 1998 haze episode, Atmos. Environ., 33, 3651-3658, 1999.

Radzi bin Abas, M., Oros, D. R., and Simoneit B. R.: Biomass burning as the main source of organic aerosol particulate matter in Malaysia during haze episodes, Chemosphere, 55(8), 10891095, 2004.

Ramdahl, T.: Retene - a molecular marker of wood combustion in ambient air, Nature, 306, 580-582, 1983.

Ray, J. and Mcdow, S. R.: Dicarboxylic acid concentration trends and sampling artifacts, Atmos. Environ., 39, 7906-7919, 2005.

Rinehart, L. R., Fujita, E. M., Chow, J. C., Magliano, K., and Zielinska, B.: Spatial distribution of $\mathrm{PM}_{2.5}$ associated organic compounds in central California, Atmos. Environ., 40, 290-293, 2006.

Rogge, W. F., Hildemann, L. M., Mazurek, M. A., Cass, G. R., and Simoneit, B. R. T.: Sources of fine organic aerosol9.Pine,oak, and synthetic log combustion in residential fireplaces, Environ. Sci. Technol., 32, 13-22, 1998.

Rogge, W. F., Mazurek, M. A., Hildemann, L. M., Cass, G. R., and Simoneit, B. R. T.: Quantification of urban organic aerosols at molecular level: identification, abundance and seasonal variation, Atmos. Environ., 27A, 1309-1330, 1993.

Rolph, G. D.: Real-time Environmental Applications and Display sYstem (READY) Website, available at: http://www.arl.noaa. gov/ready/hysplit4.html, NOAA Air Resources Laboratory, Silver Spring, MD, USA, 2003.

Salam, A., Bauer, H., Kassin, K., Ullah, S. M., and Puxbaum, H.: Aerosol chemical characteristics of a mega-city in Southeast Asia (Dhaka-Bangladesh), Atmos. Environ., 37, 2517-2528, 2003.

Schauer, J. J., Kleeman, M. J., Cass, G. R., and Simoneit, B. R. T.: Measurement of emissions from air pollution sources: 3 . C1-C-29 organic compounds from fireplace combustion of wood, Environ. Sci. Technol., 35, 1716-1728, 2001.

Schauer, J. J., Rogge, W. F., Hildemann, L. M., Mazurek, M. A., Cass, G. R., and Simoneit, R. T.: Source apportionment of airborne particulate matter using organic compounds as tracers, Atmos. Environ., 41, 241-259, 2007.

See, S. W., Balasubramanian, R., and Wang, W.: A study of the physical, chemical, and optical properties of ambient aerosol particles in Southeast Asia during hazy and nonhazy days, J. Geophys. Res.-Atmos., 111(D10), D10S08, doi:10.1029/2005JD006180, 2006.

Seinfeld, J. H. and Pankow, J. F.: Organic atmospheric particulate material, Annu. Rev. Phys. Chem., 54, 121-140, 2003. 
Simo, R., Grimalt, J. O., and Albaiges, J.: Loss of unburned fuel hydrocarbons from combustion aerosols during atmospheric transport, Environ. Sci. Technol., 31, 2697-2700, 1997.

Simoneit, B. R. T.: Application of molecular markers analysis to reconcile sources of carbonaceous particulates in tropospheric aerosols, Sci. Total Environ., 36, 61-72, 1984.

Simoneit, B. R. T.: Organic matter of the troposphere-V: application of molecular marker analysis to biogenic emissions into the troposphere for source reconciliations, J. Atmos. Chem., 8, 251275, 1989.

Simoneit, B. R. T.: Biomass burning - a review of organic tracers for smoke from incomplete combustion, Appl. Geochem., 17, 129-162, 2002.

Simoneit, B. R. T., Chester, R., and Eglinton, G.: Biogenic lipids in particulates from the lower atmosphere over the eastern Atlantic, Nature, 267, 682-685, 1977.

Simoneit, B. R. T. and Mazurek, M.: Organic matter of the troposphere-II, Natural background of biogenic lipid matter in aerosols over the rural western United States, Atmos. Environ., 16, 2139-2159, 1982.

Simoneit, B .R. T., Sheng, G. Y., Chen, X., Fu, J. M., Zhang, J., and $\mathrm{Xu}$, Y.: Molecular marker study of extractable organic matter in aerosols from urban areas of China, Atmos. Environ., 25a, 21112129, 1991.

Simoneit, B. R. T., Schauer, J. J., Nolte, C. G., Oros, D. R., Elias, V. O., Fraser, M. P., Rogge, W. F., and Cass, G. R.: Levoglucosan, a tracer for cellulose in biomass burning and atmospheric particles, Atmos. Environ., 33, 173-182, 1999.

Siniarovina, U. and Engardt, M.: High-resolution model simulations of anthropogenic sulphate and sulphur dioxide in Southeast Asia, Atmos. Environ., 39, 2021-2034, 2005.

Standley, L. J. and Simoneit, B. R. T.: Resin diterpenoids as tracers for biomass combustion aerosols, J. Atmos. Chem., 18, 1-15, 1994.

Stephanou, E. G.: Oxocarboxylic and $\alpha$, $\omega$-dicarboxylic acids: photo-oxidation products of unsaturated fatty acids,present in marine aerosols and marine sediments, Naturwissenschaften, 79, p. 128, 1993.

Stohl, A.: Computation, accuracy and applications of trajectories A review and bibliography, Atmos. Environ., 32, 947-966, 1998.
Stohl, A. and Seibert, P.: Accuracy of trajectories as determined from the conservation of meteorological tracers, Q. J. Roy. Meteor. Soc., 124, 1465-1484, 1998.

Stohl, A., Andrews, E., Burkhart, J. F., Forster, C., Herber, A., Hoch, S. W., Kowal, D., Lunder, C., Mefford, T., Ogren, J. A., Sharma, S., Spichtinger, N., Stebel, K., Stone, R., Torseth, K., Wehrli, C., and Yttri, K. E.: Pan-Arctic enhancements of light absorbing aerosol concentrations due to North American boreal forest fires during summer 2004, J. Geophys. Res. Atmos., 22, D22214, doi:10.1029/2006JD007216, 2006.

Takeuchi, N., Nakajima, T., Takamura, T., Ru, J., Arief, M., Kaneta, S., and T. U.: Optical properties of Indonesian forest fire smoke observed by satellite and on the ground in An environmental study of the Indonesian fire smoke disaster, The University of Tokyo, 30-42, 1998.

Ward, T. J., Hamilton, R. F., Dixon, R. W., Paulsen, M., and Simpson, C. D.: Characterization and evaluation of smoke tracers in PM: Results from the 2003 Montana wildfire season, Atmos. Environ., 40, 7005-7017, 2006.

Wu, S. P., Tao, S., Zhang, Z. H., Lan, T., and Zuo, Q.: Distribution of particle-phase hydrocarbons,PAHs and OCPs in Tianjin, China, Atmos. Environ., 39, 7420-7432, 2005.

Yassaa, N., Meklati, B. Y., Cecinato, A., and Marino, F.: Particulate n-alkanes, n-alkanoic acids and polycyclic aromatic hydrocabons in the atmosphere of Algiers City Area, Atmos. Environ., 35, 1843-1851, 2001.

Young, L. H.: Characterization of n-alkanes in $\mathrm{PM}_{2.5}$ of the Taipei aerosol, Atmos. Environ., 36, 477-482, 2002.

Yunker, M. B., Macdonald, R. W., Vingarzan, R., Mitchell, R. H., Goyette, D., and Sylvestre, S.: PAHs in the Fraser River basin: a critical appraisal of $\mathrm{PAH}$ ratios as indicators of PAH source and composition, Org. Geochem., 33, 489-515, 2002.

Yunker, M. B., Snowdon, L. R., Macdonald, R. W., Smith, J. N., Fowler, M. G., Skibo, D. N., McLaughlin, F. A., Danyushevskaya, A. I., Petrova, V. I., and Ivanov, G. I.: Polycyclic aromatic hydrocarbon composition and potential sources for sediment samples from the Beaufort and Barents Seas, Environ. Sci. Technol., 30, 1310-1320, 1996.

Zheng, M., Fang, M., Wang, F., and To, K. L.: Characterization of the solvent extractable organic compounds in $\mathrm{PM}_{2.5}$ aerosols in Hong Kong, Atmos. Environ., 34, 2691-2702, 2000. 